\title{
The Influence of Pesticides on the Biology and Physiology of the Land Snail Bulimulus tenuissimus (Orbigny, 1935)
}

\author{
Iza Patrício ${ }^{1}$, Florence Gonçalves Martins ${ }^{2}$, Tatiane Cristina dos Santos
} Bonfim $^{2}$, Mauricio Carvalho de Vasconcellos ${ }^{1}$, Jairo Pinheiro ${ }^{3}$, Marta Julia Faro $^{4}$, Clélia Christina Mello-Silva ${ }^{1}$

\footnotetext{
${ }^{1}$ Grupo de pesquisa em Saúde e Educação Ambiental Crítica com Ênfase nas Relações Parasitárias do Laboratório de Avaliação e Promoção da Saúde Ambiental, IOC, FIOCRUZ, Av. Brasil 4365, Manguinhos, 21040-900, RJ, Brazil Email: izapattricio@gmail.com, mau@ioc.fiocruz.br, clelia@ioc.fiocruz.br ${ }^{2}$ Curso de Pós-Graduação em Ciências Veterinárias, Instituto de Veterinária, UFRRJ, BR 465, km 47, 23897-000, Seropédica, RJ, Brazil Email: florencegmartins@gmail.com, tatianecdsb@hotmail.com

${ }^{3}$ Departamento de Ciências Fisiológicas, Instituto de Ciências Biológicas e da Saúde, UFRRJ, BR 465, km 47, 23897-000, Seropédica, RJ, Brazil

Email: jairopinheirodasilva@gmail.com

${ }^{4}$ Laboratório de Biologia e Parasitologia de Mamíferos Silvestres Reservatórios, IOC, FIOCRUZ, Av. Brazil 4365, Manguinhos, $21040-$ 900 RJ, Brazil

Email: martajulia.ioc.fiocruz@gmail.com

Corresponding author: clelia@ioc.fiocruz.br
}

\begin{abstract}
Some terrestrial gastropods are agricultural pests and are exposed to toxic products capable of causing physiological and biological alterations. The action of some herbicides and molluscicides has been studied on freshwater snails, but there are few studies of terrestrial species. This study analyzed the biological and physiological responses of Bulimulus tenuissimus exposed to the natural molluscicidal latex of Euphorbia milii var. hislopii and the synthetic herbicide Roundup ${ }^{\circledR}$ Original. A total of 210 snails were divided and exposed for 24 hours to the products (latex or herbicide in concentrations of 1,000 ppm and 100,000 ppm) and type 2 water. Of this total, 150 exposed animals were analyzed biochemically after 24 hours, and the others were observed during 30 days for analysis of the mortality rate. After 24 hours, some snails presented escape mechanisms such as epiphragm formation, cephalopedal mass retraction and burial. The latex did not cause metabolic alterations but the herbicide altered the carbohydrate metabolism of B. tenuissimus, reducing energy substrates in the sites analyzed (hemolymph, digestive gland and cephalopedal mass). Regarding the protein metabolism, there was no alteration after exposure to both analyzed substances. After 30 days of exposure, higher mortality was recorded for the groups exposed to the herbicide. These findings suggest that $B$. tenuissimus is resistant to the molluscicidal latex of Euphorbia milii var. hislopii more than the herbicide Roundup ${ }^{\circledR}$ Original.
\end{abstract}

Keywords- Bulimulus tenuissimus, carbohydrate metabolism, Euphorbia milii var. hislopii, Roundup ${ }^{\circledR}$ Original.

\section{INTRODUCTION}

Agrotoxics are substances used to increase agricultural productivity through pest and disease control [1]. However, their indiscriminate use can cause serious damage to the environment and to human health, as well as putting selective pressure for development of resistance by pests [2].

Brazil has been the largest consumer of agrotoxics in the world since 2008 according to data from the Brazilian
Institute of Geography and Statistics (IBGE) [3], with numerous active principles and commercial formulations, which can be classified according the action on the target organism and the chemical group to which they belong [2]. Of the agrotoxics used in Brazil, 56\% are herbicides [4]. Among the commonly used Roundup ${ }^{\circledR}$ stands out, which has as its active ingredient Glyphosate (N(phosphonomethyl) glycine) combined with a surfactant that facilitates transport by the plant. It is a non-selective 
herbicide, effective in the total destruction of weeds [5], and in the control of plants in reforestation, gardens and aquatic plants in fish farming tanks and in lakes [6]. From the Roundup® herbicide several formulations were commercialized by the Monsanto Company, one of them is Roundup ${ }^{\circledR}$ Original, which presents polyoxyethylene amine surfactant (POEA), which helps the herbicide to penetrate the leaves of plants [7]. Some herbicides have deleterious effects on limnic mollusks, interfering at the cellular and physiological, molecular level to reduce the survival rate and reproductive activity $[8,9,10]$.

Molluscicide is the classification of agrotoxic for control of mollusks present in gardens, fields and greenhouses, including those that are intermediate hosts of parasites in aquatic environments, such as snails that transmit schistosomiasis. Poisoning by such substances can cause osmotic imbalance, and as a consequence two mechanisms that cause mortality may occur: retraction of the cephalopedal mass with the release of hemolymph and/or abnormal projection out of the shell [11], called "distress syndrome".

Molluscicides can be synthetic or natural. Chemical control of terrestrial species occurs mainly through synthetic molluscicides. Although effective, these compounds also act on non-target organisms, causing significant changes in ecosystems [12]. As a consequence, there is increasing demand for readily biodegradable substances as an alternative to synthetic molluscicides [13].

The latex of Euphorbia milii var. hislopii (N. E. B.) (Euphorbiaceae), popularly known as crown of thorns, Christ plant, or Christ thorn, is considered one of the most promising Brazilian molluscicides. In laboratory and field conditions it complies with the recommendations of the World Health Organization (WHO) for use as a natural molluscicide, in addition to being biodegradable and less hazardous to non-target organisms [14], with effective results on limnic mollusks and amphibians [15].

The land snail Bulimulus tenuissimus (Orbigny, 1935) is present in many Brazilian regions [16], where it is considered an agricultural pest. It is also the only species in the family Bulimulidae cited as an intermediate host of some parasites of poultry [17]. Recently, studies showed that this mollusk is host of the nematode Angiostrongylus cantonensis (Chen, 1935) [18,19], a rodent lung parasite capable of infecting humans and causing meningitis, characterized by eosinophilic inflammation [20].

Studies of synthetic or natural substances for the control of terrestrial species are scarce, as well as the physiological changes induced by these substances. For this reason, this study analyzed the biological and physiological responses of $B$. tenuissimus exposed to the natural molluscicide latex of E. milii var. hislopii and the synthetic herbicide Roundup® Original.

\section{MATERIAL AND METHODS}

\subsection{Determining concentrations of $E$. milii var. hislopii latex and Roundup ${ }^{\circledR}$ Original}

The crude latex extract was collected in the Ilha do Governador district $\left(22^{\circ} 48^{\prime} 09^{\prime \prime} \mathrm{S} / 43^{\circ} 12^{\prime} 35^{\prime \prime} \mathrm{W}\right)$ of the city of Rio de Janeiro, Brazil. Determination of the concentrations of the two substances was based on the procedures described by Vasconcellos and Amorim [21], and based on pre-tests, concentrations of 1,000 ppm (parts per million) $(0.1 \%)$ and $100,000 \mathrm{ppm}(10 \%)$ for both substances were chosen $(\mathrm{mg} / \mathrm{L}$ for latex and $\mathrm{ml} / \mathrm{L}$ for herbicide).

\subsection{Formation of groups}

The parents of the snails used were obtained in a garden located in the municipality of Seropédica, Rio de Janeiro,

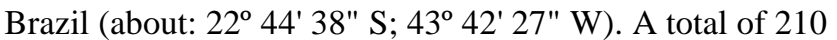
hatched mollusks were kept in the Laboratory for Evaluation and Promotion of Environmental Health of Fiocruz in Rio de Janeiro, where they were monitored until reaching sexual maturity (110 days).

For the 24-hour and 30-day follow-up, the snails were divided into five groups, with 30 and 12 specimens each, respectively: two groups exposed to latex (L) at concentrations of 1,000 ppm and 100,000 ppm (L1,000 and L100,000, respectively); two groups exposed to Roundup ${ }^{\circledR}$ Original (R) (R1,000 and R100,000, respectively); and one control group sprayed with type 2 water.

\subsection{Exposure}

For the 24-h follow-up, 150 mollusks were exposed individually in disposable flasks with a capacity of $150 \mathrm{ml}$ containing $50 \mathrm{~g}$ of sterile soil moistened with water. Addition of the compounds was done by spraying the concentrations prepared for each product using $5 \mathrm{ml}$ glass hand sprayers. Each mollusk received $2 \mathrm{ml}$ of the product corresponding to its group, under a fume hood. Twentyfour hours after exposure, the specimens were observed and dissected for the collection of biological samples.

For the 30-day follow-up, the exposure occurred plastic terrariums with $12 \mathrm{~cm}$ in diameter and $8 \mathrm{~cm}$ in depth, containing $3 \mathrm{~cm}$ of moistened sterilized soil as substrate. Each terrarium received $24 \mathrm{ml}$ of the substance corresponding to its group through glass sprayers: $2 \mathrm{ml}$ of the corresponding substance was sprayed onto each mollusk, under a fume hood. They were observed every 
other day for 30 days (four weeks) after exposure to determine the mortality rate.

In both cases, the control groups were sprayed with $2 \mathrm{ml}$ of type 2 water.

\subsection{Collection of hemolymph and dissection after 24 hours}

After 24 hours of exposure, 150 snails (30 specimens from each group) were dissected. The hemolymph was collected by extravasation from the apex rupture of the shell, collected in microtubes, kept in an ice bath at $10{ }^{\circ} \mathrm{C}$ and then stored at $-20{ }^{\circ} \mathrm{C}$ in a freezer until the biochemical analyses [18].

The specimens were dissected in Petri dishes and the cephalopedal mass and digestive gland tissues were kept separately in an ice bath at $10{ }^{\circ} \mathrm{C}$ during collection to avoid enzymatic degradation of carbohydrates. Subsequently, the samples were weighed and stored at -20 ${ }^{\circ} \mathrm{C}$ in a freezer until use.

\subsection{Biochemical analysis}

The hemolymph was analyzed with a BioSystems A15 automatic biochemical analyzer, with reading through the use of reagent kits for biochemical analysis prepared for glucose, total protein and lactate dehydrogenase (LDH E.C. 1.1.1.27).

Glycogen extraction from the digestive gland and cephalopedal mass was performed as described by Pinheiro and Gomes [22] and quantified through the 3,5 dinitrosalicylate (DNS) technique [23], with results expressed as $\mathrm{mg}$ of glucose/g tissue, fresh weight.

\subsection{Maintenance of the terrariums}

The feed consisted of $3 \mathrm{~g} \pm 1 \mathrm{~g}$, of chayote (Sechium edule) and carrot (Daucus carota), plus lettuce leaves (Lactuca sativa) ad libitum. In natura. The feed was supplemented with bird feed enriched for growth with calcium carbonate in proportion of 3:1 [24], served in plastic containers $(3 \mathrm{~cm}$ in diameter and $0.5 \mathrm{~cm}$ in depth [25]. All feed was changed every two days. The soil sprinkled with the substances was kept in the terrariums until the end of the experiment (30 days).

\subsection{Mortality records}

The terrariums were observed every two days, for 30 days (four weeks), for quantification and removal of dead snails. The mortality rate was expressed as a percentage $(\%)$.

\subsection{Statistical analyses}

The results were expressed as mean \pm standard error of the mean, and were submitted one-way analysis of variance (ANOVA) followed by the Tukey-Kramer test $(\alpha=5 \%)$ to compare the means (GraphPad InStat and GraphPad Prism, v. 6., Prism Inc.).

\section{RESULTS}

After 24 hours of exposure, exhaust mechanisms, characterized by increased mucus release and presence of epiphragm, were observed in the snails of all groups exposed to both toxic products. Also, in the L1,000 group, burial behavior occurred, and in the R1,000 group, cephalopedal mass retraction was observed.

Significant reductions of $29.99 \%, 24.21 \%$ and $12.21 \%$ in the glycogen content of the digestive gland were observed in the groups L100,000 (17.09 \pm 0.29), R1,000 (18.5 \pm $0.66)$ and $\mathrm{R} 100,000(21.43 \pm 0.77)$, respectively, in relation to the control group $(24.41 \pm 0.37)$. However, a non-significant increase was observed of $7.57 \%$ in the group L1,000 $(26.26 \pm 0.66)$ in relation to the control group (Fig. 1A).

The pattern was repeated for glycogen content in the cephalopedal mass, with significant reductions of $37.9 \%$, $60.63 \%, 28.66 \%$ in groups L100,000 (18.96 \pm 0.02$)$, $\mathrm{R} 1,000(12.02 \pm 0.14)$ and $\mathrm{R} 100,000(21.78 \pm 0.03)$, respectively, in relation to the control group (30.53 \pm 0.08). And group L1,000 (35.83 \pm 0.14$)$ presented a significant increase of $17.36 \%$ compared to the control group (Fig. 1B).
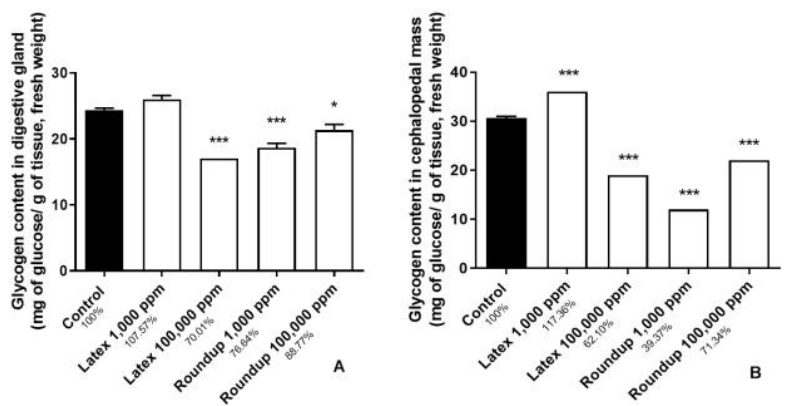

Fig. 1. Changes in the glycogen content (mg of glucose/g tissue, fresh weight) in Bulimulus tenuissimus tissues exposed to two concentrations of natural molluscicide latex of E. milii var. hislopii and the synthetic herbicide Roundup ${ }^{\circledR}$ Original. A Digestive gland. B Cephalopedal mass ( $p$ value $<0.0001$, strongly significant).

$(\mathrm{P}<0.001 * * *$, strongly significant/ $\mathrm{P}<0.01 * *$, significant / $\mathrm{P}<0.05^{*}$, weakly significant difference/ $\mathrm{P}>0.05$ no significant difference in relation to the control group).

The glucose concentration in the hemolymph showed significant reductions of $72.08 \%$ and $74.99 \%$, respectively, in the $\mathrm{L} 1,000(6.33 \pm 0.88)$ and $\mathrm{R} 100,000(5.67 \pm 1.2)$ groups in relation to the control $(22.67 \pm 1.2)$. The decrease of $29.42 \%$ observed in group R1,000 (16 \pm 0.0 ) was not significantly different than the control. In addition, a non-significant increase of $27.92 \%$ in the L100,000 group $(29 \pm 3.05)$ was observed compared to the control group (Fig. 2A). 
The analysis of lactate dehydrogenase (LDH) activity in hemolymph showed increases in activity of $48.43 \%$ and $65.85 \%$ in L100,000 (142 \pm 43.15$)$ and R1,000 (158.67 \pm 2.73), respectively, after 24 hours of exposure. Moreover, reductions of $46.69 \%$ and $38.68 \%$ of this activity were observed in $\mathrm{L} 1,000(51 \pm 6.03)$ and $\mathrm{R} 100,000(58 \pm$ 12.44), respectively. However, no significant differences were observed in relation to the control group (95.67 \pm 12.55) (Fig. 2B).
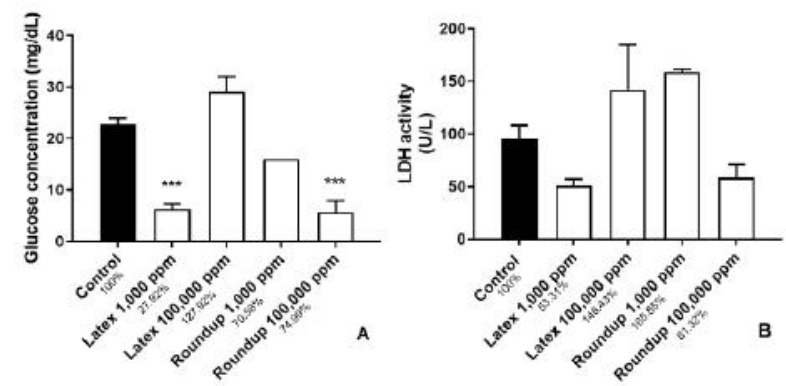

Fig. 2. A Glucose concentration expressed in $\mathrm{mg} / \mathrm{L}$

$(P<0.0001$, strongly significant) and $\boldsymbol{B}$ Lactate

dehydrogenase $(L D H)$ activity expressed in $U / L(P=$ 0.0153, significant) in Bulimulus tenuissimus hemolymph after 24 hours of exposure to Euphorbia milii var. hislopii

latex and the synthetic herbicide Roundup ${ }^{\circledR}$ Original. $(\mathrm{P}<0.001 * * *$, strongly significant/ $\mathrm{P}<0.01 * *$, significant / $\mathrm{P}<0.05^{*}$, weakly significant difference/ $\mathrm{P}>0.05$ no significant difference in relation to the control group).

Exposure to the toxic substances caused non-significant reductions in circulating concentration of protein in the hemolymph of $33.35 \%, 1.27 \%$ and $28.19 \%$ in the $\mathrm{L} 1,000$ $(17.33 \pm 2.85) \mathrm{L} 100,000(25.67 \pm 3.48)$ and R100,000 $(18.67 \pm 4.70)$ groups, respectively, compared to the control group $(26 \pm 3.46)$. In R1,000 there was a $33.34 \%$ increase in this parameter $(34.67 \pm 0.3)$ (Fig. 3).

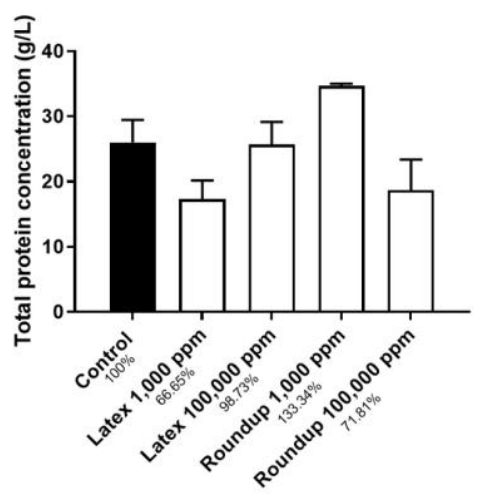

Fig. 3. Circulating protein concentration, expressed in $\mathrm{g} / \mathrm{L}$ of Bulimulus tenuissimus hemolymph after 24 hours of exposure to Euphorbia milii var. hislopii latex and the synthetic herbicide Roundup ${ }^{\circledR}$ Original.
$(\mathrm{P}<0.001 * * *$, strongly significant/ $\mathrm{P}<0.01 * *$, significant / $\mathrm{P}<0.05^{*}$, weakly significant difference/ $\mathrm{P}>0.05$ no significant difference in relation to the control group).

Dead mollusks were found in terrariums after 24 hours in the R100,000 group, after 48 hours in the R1,000 group, 96 hours in the L100,000 group and 168 hours in the L1,000 group.

For mortality of B. tenuissimus after 30 days (720 hours), the exposure to the synthetic herbicide in the groups $\mathrm{R} 1,000$ and R100,000 caused mortality rate of $91.67 \%$. In the L1,000 and L100,000 groups, these rates were $75 \%$ and $83.33 \%$, respectively, for the exposed snails. The control group had a $75 \%$ mortality rate (Table 1 ).

Table 1. Mortality rate of Bulimulus tenuissimus accompanied for 30 days after exposure to Euphorbia milii var. hislopii $(L)$ latex and the synthetic herbicide Roundup ${ }^{\circledR}$ Original $(R)$.

\begin{tabular}{|c|c|c|c|c|c|}
\hline \multirow{2}{*}{$\begin{array}{l}\text { Hours of } \\
\text { exposure } \\
\text { (h) }\end{array}$} & \multicolumn{5}{|c|}{ Exposed groups } \\
\hline & Control & $\mathrm{L} 1,000$ & L100,000 & $R 1,000$ & R100,000 \\
\hline 24 & - & - & - & - & 1 \\
\hline 48 & - & - & - & 1 & - \\
\hline 72 & - & - & - & - & - \\
\hline 96 & - & - & 1 & 1 & 2 \\
\hline 168 & 2 & 3 & 4 & 3 & 2 \\
\hline 336 & - & 2 & 2 & 3 & 3 \\
\hline 504 & 3 & 1 & 2 & 1 & 2 \\
\hline 720 & 4 & 3 & 1 & 2 & 1 \\
\hline $\begin{array}{l}\text { Total no. of } \\
\text { dead snails }\end{array}$ & $9(75 \%)$ & $9(75 \%)$ & $10(83.33 \%)$ & $11(91.67 \%)$ & $11(91.67 \%)$ \\
\hline $\begin{array}{l}\text { N- Survival } \\
\text { percentage } \\
(\%)\end{array}$ & $3-25 \%$ & $3-25 \%$ & $2-16.63 \%$ & $1-8.33 \%$ & $1-8.33 \%$ \\
\hline
\end{tabular}

\section{DISCUSSION}

Land mollusks can present physiological and behavioral strategies to ensure their survival under unfavorable conditions, such as estivation, retraction of the cephalopedal mass, and burial [26, 27], all of which can favor survival after exposure to molluscicides [28].

In this study, the first reaction to the toxic substances, observed after 24 hours of exposure, was increased release of mucus in all terrariums containing exposed mollusks. According to the literature, increased mucus production and secretion is one of the first reactions of gastropods to stress, among them chemical irritation caused by molluscicidal products [29]. Other strategies, such as cephalopedal mass retraction and epiphragm formation, were also observed in the present study after stress, corroborating the finding of D'ávila and collaborators, who examined Bradybaena similaris (Férussac, 1821), Leptinaria unilamellata (d'Orbigny, 1837) and Subulina octona (Bruguiière, 1789) at a constant temperature of 35 ${ }^{\circ} \mathrm{C}$ for 48 hours and observed cephalopedal mass retraction after $12 \mathrm{~h}$ of exposure and the presence of epiphragm in four replicates of $B$. similaris with 24 hours of exposure [30]. 
Exposure to toxic substances can alter the physiological homeostasis of an organism [31,32,33]. Silva et al. [34]., exposing $B$. similaris to the $\mathrm{LC}_{50}$ of the aqueous extract of Solanum peniculatum L. (Solanaceae) for $72 \mathrm{~h}$, observed after $24 \mathrm{~h}$ an increase in the carbohydrate content of the digestive gland and the concentration of glucose in the hemolymph, and a significant reduction of carbohydrates in the cephalopedal mass. According to the authors, this profile demonstrates the existence of metabolic compensation for the regulation of homeostasis in the organism [34].

In the present study, the L1,000 group showed an increase in glycogen content in the digestive gland and cephalopedal mass, and a significant reduction of glucose concentration in the hemolymph. In the L100,000 group, there was a significant reduction of the glycogen content in the tissues and an increase in the glucose concentration in the hemolymph. In this respect, according to Pinheiro et al. [35], mollusks mainly use glycogen stores in the digestive gland and muscle tissue to maintain normoglycemia in the hemolymph. This explains our observation that the snails in group L100,000 had tendency to stabilize the glucose in the organism through gluconeogenesis to maintain homeostasis. In the L1,000 group, the energy metabolism was maintained through the consumption of free glucose in the hemolymph, causing accumulation of glycogen in the tissues, to guarantee the regulation of glycemia.

Unlike latex, the exposure to the herbicide Roundup® Original caused reductions in glucose concentration in the hemolymph and glycogen content in the digestive gland and cephalopedal mass of B. tenuissimus. Barky et al. [36], when exposing Biomphalaria alexandrina to the $\mathrm{LC}_{10}$ of the herbicides Atrazine (0.33 ppm) and Roundup ${ }^{\circledR}(0.84$ $\mathrm{ppm}$ ) for four weeks, observed an increase in glucose concentration in the hemolymph and reduction of glycogen content in the tissues of these animals, a different pattern than the present study.

$\mathrm{LDH}$ is an enzyme involved in the activation of anaerobic metabolism, and its measurement can be used to understand energy production by mollusks, which can occur either aerobically or anaerobically. Silva et al. found a significant increase in $\mathrm{LDH}$ activity in $B$. similaris after $24 \mathrm{~h}$ exposure to the $\mathrm{LC}_{50}$ of the aqueous extract of $S$. paniculatum. According to the authors, acceleration of anaerobic metabolism occurred, a possible consequence of intoxication [34]. In the current study, the results obtained show that the different concentrations of the molluscicide latex and herbicide did not significantly alter LDH activity, so that aerobic metabolism was maintained.

Faced with a deficiency of energy substrates first consumed in the body, mollusks can search for proteins as an alternative means of obtaining energy [37]. In this study, the total protein concentration in the exposed groups did not differ significantly from the control group, showing that it was not necessary to use this source for homeostatic maintenance.

Regarding the mortality of $B$. tenuissimus during 30 days of exposure, the first deaths occurred in 24 and 48 hours for the groups exposed to the herbicide. Mortality after exposure to the latex was slower, with the first death occurring after exposure for $96 \mathrm{~h}$. Mortality was recorded until the end of $720 \mathrm{~h}$ at both concentrations. Afonso-Neto et al. [38], submitting a terrestrial gastropod to the latex of three Euphorbiaceae species, verified that E. milii var. hislopii was able to kill $100 \%$ of the specimens within 24 hours after exposure to the different dilutions, and highlighted the decrease of the latex effect revealed by $25 \%$ mortality after exposure to the concentration of 1 : $1,000 \mathrm{ml} / \mathrm{ml}$ of the product.

The WHO determines that the concentrations used for natural molluscicides in aquatic mollusks are $20 \mathrm{ppm}$ for plant extracts and $100 \mathrm{ppm}$ for the raw plant) [39], and the literature does not find dosage recommendations for land mollusks species [40]. In this study, the concentrations used for the molluscicide exceeded the limit determined by the WHO. In our work, the concentrations of herbicides were equal or higher than those used by other authors, using the profile mollusk vs. herbicide $[8,9,10,36]$. The specimens of $B$. tenuissimus was able quickly recovery of homeostasis

The use of agricultural chemicals in plantations is common [41], in Brazil. The applications of these substances are justified by the fact that about $10 \%$ of the harvest is lost due to the presence of different agricultural pests in the cultivation system [42]. Because of this, the resistance or resilience to pesticides found in this work in B. tenuissimus can be explained in two ways: the first related to the habit of mollusks to feed on vegetations with pesticides and the other through the generation of phenotypes of resistance induced by selective pressure imposed by the frequent use of pesticides. The resilience and persistence of invertebrates is explained in the literature [43, 44] and according to Brigante et al. [45] are characteristics of biondicator species such as land mollusks.

\section{CONCLUSION}

In our study, B. tenuissimus showed resistance to high concentrations of pesticides. The snails were able to survive exposure to Roundup ${ }^{\circledR}$ Original at both concentrations used in this work, but the energy metabolism was altered. New studies on the behavioral, physiological and epigenetic effects of pesticides on these 
land snails are already underway. These studies are necessary because these mollusks have wide geographical distribution, are considered agricultural pests and are intermediate hosts of Angiostrongylus cantonensis, etiological agent of eosinophilic meningoencephalitis.

\section{ACKNOWLEDGEMENTS}

We thank Anna Carla Alberto, Vanessa Valladares, Jessica Fabíola dos Santos, Gabriela Friani and Érica Tex for lab assistance.

\section{REFERENCES}

[1] Koustas, R.N., Fischer, D., 1998. Review of separation Technologies for treating pesticide-contaminated soil. Journal of the Air \& Waste Management Association, 48, 234-440. https://doi.org/10.1080/10962247.1997.11877501.

[2] Peres, F., Moreira, J.C., 2007. Saúde e ambiente em sua relação com o consumo de agrotóxicos em um pólo agrícola do Estado do Rio de Janeiro, Brasil. Cadernos de Saúde Pública, 23, 612-621.

[3] Santana, V.S., Moura, N.C.P., Nogueira, F.F., 2013. Occupational pesticide poisoning mortality, 2000-2009, Brazil. Revista de Saúde Pública, 47, 598-606. http://dx.doi.org/10.1590/S0034-8910.2013047004306.

[4] Racke, K.D., Skidmore, M.W., Hamilton, D.J., Unsworth, J.B., Miyamoto, J., Cohen, S.Z., 1997. Pesticide Fate in Tropical Soils. Pure \& Applied Chemistry, 69, 1349-1371.

[5] Carvalho, S.J.P., Damin, V., Dias, A.C.R., Melo, M.S.C.; Nicolai, M., Christoffoleti p, J., 2009. Dessecação de plantas daninhas com glyphosate em mistura com ureia ou sulfato de amônio. Planta Daninha. 27, 353-361.

[6] Neskovic, N.K., Poleksic, V., Elezovic, I., Karan, V., Budimir, M., 1996. Biochemical and histopathological effects of glyphosate on carp (Cyprinus carpio). Bulletin of Environmental Contamination and Toxicology. 56, 295-302. https://doi.org/10.1007/s001289900044.

[7] Jiraungkoorskul, W., Upatham, E.S., Kruatrachue, M., Sahaphong, S.; Vichasi-Grams, S., Pokethitiyook, P., 2002. Histopathological effects of Roundup, a glyphosate herbicide, on nile tilapia (Oreochromis niloticus). Science Asia. 28, 121127.

[8] Abdel-Ghaffar, E., Ahmed, A.K., Bakry, F., Rabei, I., Ibrahim, A., 2016. The Impact of Three Herbicides on Biological and Histological Aspects of Biomphalaria alexandrina, Intermediate Host of Schistosoma mansoni, Malacologia. 59,197-210. https://doi.org/10.4002/040.059.0201.

[9] Mona, M.H., Gaafar, R.M., Helal, I.B., Omran, N.E., Salama, W.M., 2013. Evaluation of cytotoxic effects of atrazine and glyphosate herbicides on Biomphalaria glabrata snails. The Journal of Basic \& Applied Zoology. 66, 68-75. https://doi.org/10.1016/j.jobaz.2013.05.004.

[10] Hasheesh, W.S., Mohamed, R.T., 2011. Bioassay of two pesticides on Bulinus truncatus snails with emphasis on some biological and histological parameters. Pesticide Biochemistry and Physiology. 100, 1-6 https://doi.org/10.1016/j.pestbp.2011.01.008.
[11] Mccullough, F.S., Gayral, P., Duncan, J., Christie, J.D., 1980. Molluscicides in schistosomiasis control. Bulletin of the World Health Organization. 58, 681.

[12] Cantanhede, S.P.D., Marques, A.D.M., Silva-Souza, N., Valverde, A.L., 2010. Atividade moluscicida de plantas: uma alternativa profilática. Revista Brasileira de Farmacognosia. 20, 282-288.

[13] Sturrock, R.F., 1995. Current concepts of snail control. Memórias do Instituto Oswaldo Cruz, 90, 241-248. http://dx.doi.org/10.1590/S0074-02761995000200020.

[14] Vasconcellos, M.C., Amorim, A., 2003. Activity of Euphorbia splendens var. hislopii N.E.B (Euphorbiaceae) latex against Lymnaea columella (Say, 1817) (Pulmonata: Lymnaeidae), intermediate host of Fasciola hepatica, Linnaeus, 1758 (Trematoda: Fasciolidae). 2: limited field-testing. Memórias do Instituto Oswaldo Cruz, 98, 981-985. http://dx.doi.org/10.1590/S0074-02762003000700021.

[15] Vasconcellos, M.C., Schall, V.T., 1986. Latex of "Coroa de Cristo" (Euphorbia splendens): an effective molluscicide. Memórias do Instituto Oswaldo Cruz. 81, 475476. http://dx.doi.org/10.1590/S0074-02761986000400017.

[16] Carvalho, O.D.S., Scholte, R.G.C., Mendonça, C.L.F.D., Passos, L.K.J., Caldeira, R.L. (2012). Angiostrongilus cantonensis (nematode: Metastrongyloidea) in molluscs from harbor areas in Brazil. Memórias do Instituto Oswaldo Cruz, 107, 740-746. http://dx.doi.org/10.1590/S007402762012000600006 .

[17] Thiengo, S.C., Amato, S.B., 1995. Phyllocaulis variegatus (Mollusca: Veronicellidae), a new intermediare host for Brachylaima sp. (Digenea: Brachylaimatidae). Memórias do Instituto Oswaldo Cruz. 90, 621-622.

[18] Martins, F.G., Lima, M.G., Castro, R.N., Sant'anna, L.D.O., Santos, M.A.J., Garcia, J.S., Pinheiro, J., 2018. Bulimulus tenuissimus (mollusca) as a new potential host of Angiostrogylus cantonensis (nematoda), a histological and metabolic study. Journal of invertebrate pathology, 154, 65-73. https://doi.org/10.1016/j.jip.2018.04.003.

[19] Ramos-de-Souza, J., Thiengo, S.C., Fernandez, M.A., Gomes, S.R., Antônio, J.C., Clímaco, M.D.C., Dolabella, S.S., 2018. First records of molluscs naturally infected with Angiostrongylus cantonensis (Nematoda: Metastrongyloidea) in Northeastern Brazil, including new global records of natural intermediate hosts. Revista do Instituto de Medicina Tropical de São Paulo, 60. http://dx.doi.org/10.1590/s16789946201860051.

[20] Alicata, J.E., 1991. The discovery of Angiostrongilus cantonensis as cause of human eosinophilic meningitis. Parasitology today. 7, 151-153. https://doi.org/10.1016/01694758(91)90285-V.

[21] Vasconcellos, M.C., Amorim, A., 2003. Molluscicidal Action of the Latex of Euphorbia splendens var. hislopii NEB ("Christ's Crown") (Euphorbiaceae) against Lymnaea columella (Say, 1817) (Pulmonata: Lymnaeidae), Intermediate Host of Fasciola hepatica Linnaeus, 1758 (Trematode: Fasciolidae). 1-Test in Laboratory. Memórias do Instituto Oswaldo Cruz. 98, 557-564. http://dx.doi.org/10.1590/S007402762003000400025.

[22] Pinheiro, J., Gomes, E.M., 1994. A method for glycogen determination in molluscs. Arquivos de Biologia e Tecnologia. 37, 569-576. 
[23] Sumner, J.B., 1924. The estimation of sugar in diabetic urine, using dinitrosalicylic acid. Journal of biological chemistry. 62, 287-290.

[24] Bessa, E.C.A., Barros-Araújo, J.L., 1995. Oviposição, tamanho de ovos e medida do comprimento da concha em diferentes fases do desenvolvimento de Subulina octona (Brugüière) (Pulmonata, Subulinidae) em condições de laboratório. Revista Brasileira de Zoologia. 12, 647-654.

[25] Silva, L.C., Meireles, L.M.O., Junqueira, F.O., Bessa, E.C.A., 2008. Development and reproduction in Bulimulus tenuissimus (Mollusca: Bulimulidae) in laboratory. Revista Brasileira de Zoologia. 25, 220-223. http://dx.doi.org/10.1590/S0101-81752008000200009.

[26] Arad, Z., 1993. Water relations and resistance to dessiccation in three Israeli desert land snails, Eremina desertorum, Euchondrus desertorum and Euchondrus albulus. Journal of Arid Environments. 24, 387-395. https://doi.org/10.1006/jare.1993.1032.

[27] Emberton, K.C., 1994. Morphology and aestivation behaviour in some Madagascan acavid land snails. Biological Journal of the Linnean Society. 53, 175-187. https://doi.org/10.1111/j.1095-8312.1994.tb01008.x.

[28] Pieri, O., Jurberg, P., 1981. Aspectos etológicos na sobrevivência dos caramujos vetores da xistosomose ao tratamento com moluscicidas. Memórias do Instituto Oswaldo Cruz. 76, 47-55. http://dx.doi.org/10.1590/S007402761981000100005.

[29] Triebskorn, R., Christensen, K., Heim, I., 1998. Effect of orally and dermally applied metaldehyde on mucus cells of slugs (Deroceras reticulatum) depending on temperature and duration of exposure. Journal of Molluscan Studies. 64, 467487. https://doi.org/10.1093/mollus/64.4.467.

[30] D’ávila, S., Dias, R.J.P., Bessa, E.C.A., Daemon, E., 2004. Resistência à dessecação em três espécies de moluscos terrestres: aspectos adaptativos e significado para o controle de helmintos. Revista Brasileira de Zoociências. 6, 115-127.

[31] Mello-Silva, C.C., Vasconcellos, M.C., Pinheiro, J., Rodrigues, M.L.A., 2006. Physiological changes in Biomphalaria glabrata Say, 1818 (Pulmonata: Planorbidae) caused by sublethal concentrations of the latex of Euphorbia splendens var. hislopii NEB (Euphorbiaceae). Memórias do Instituto Oswaldo Cruz. 101, 3-8. http://dx.doi.org/10.1590/S007402762006000100002.

[32] Mello-Silva, C.C., Vilar, M.M., Bezerra, J.C., Vasconcellos, M.C., Pinheiro, J., Rodrigues, M.L.A., 2007. Reproductive activity alterations on the Biomphalaria glabrata exposed to Euphorbia splendens var. hislopii latex. Memórias do Instituto Oswaldo Cruz. 102, 671-674. http://dx.doi.org/10.1590/S007402762007005000101.

[33] Mello-Silva, C.C., Vilar, M.M., Vasconcellos, M.C., Pinheiro, J., Rodrigues, M.L., 2010. Carbohydrate metabolism alterations in Biomphalaria glabrata infected with Schistosoma mansoni and exposed to Euphorbia splendens var. hislopii latex. Memórias do Instituto Oswaldo Cruz. 105, 492495. http://dx.doi.org/10.1590/S0074-02762010000400024.

[34] Silva, L., Durço, E., Pinheiro, J., Bessa, E.C.A., 2013. Effect of Solanum paniculatum leaf extract on food consumption, fertility and carbohydrate metabolism of Bradybaena similaris snail. Journal of Natural Products. 6, 168-176.

[35] Pinheiro, J., Maldonado, A. Jr., Lanfredi, R.M., 2009. Physiological changes in Lymnaea columela (Say, 1818)
(Mollusca, gastropoda) in response to Echinostoma paraensei Lie and Basch, 1967 (Trematoda, Echinostomatidae) infection. Parasitology Reasearch. 106, 55-59. https://doi.org/10.1007/s00436-009-1630-7.

[36] Barky, F.A., Abdel-Salam, H.A., Mahmoud, M.B., Hamdi, S.A., 2012. Influence of Atrazine and Roundup pesticides on biochemical and molecular aspects of Biomphalaria alexandrina snails. Pesticide Biochemistry and Physiology. 104(1), 9-18. https://doi.org/10.1016/j.pestbp.2012.05.012.

[37] Tunholi-Alves, V.M., Tunholi, V.M., Lustrino, D., Amaral, L.S., Thiengo, S.C., Pinheiro, J., 2011. Changes in the reproductive biology of Biomphalaria glabrata experimentally infected with the nematode Angiostrongylus cantonensis. Journal of invertebrate pathology, 108, 220-223. https://doi.org/10.1016/j.jip.2011.08.009.

[38] Afonso-Neto, I.S., Bessa, E.A., Soares, G.L.G., 2010 Avaliação da atividade moluscicida do látex de três espécies de Euphorbia (Euphorbiaceae) sobre Leptinaria unilamellata D’Orbigny, 1835 (Gastropoda-Subulinidae). Revista Brasileira de Plantas Medicinais. 12, 90-95. http://dx.doi.org/10.1590/S1516-05722010000100013.

[39] WHO, World Health Organization. Guidelines for evaluation of plant molluscicides. In: Report of the scientific working group on plant molluscicide. Geneva: WHO, 1983, $11 \mathrm{p}$. Available in: <http:// http://apps. who.int/iris/bitstream/10665/60086/1/TDR_SCHSWG_4_83.3_eng.pdf>.

[40] Silva, L., Souza, B., Bessa, E.C.A., Pinheiro, J., 2012 Effect of successive applications of the sublethal concentration of Solanum paniculatum in Subulina octona (Subulinidae). Journal of Natural Products, 5, 157-167.

[41] Moreira, J.C., Jacob, S.C., Peres, F., Lima, J.S., Meyer, A., Oliveira-Silva J.J., Sarcinelli, P.N. et al., 2002. Avaliação integrada do impacto do uso de agrotóxicos sobre a saúde humana em uma comunidade agrícola de Nova Friburgo, RJ. Ciência \& Sáude Coletiva, 7:2, 299-311.

[42] Midio, A.F., Martins, D.I., 1997. Herbicidas em alimentos: aspectos gerais, toxicológicos e analíticos. São Paulo: Livraria Varela, 109p.

[43] Winterbotton, J.H., Orton, S.E., Hildrew, G., Lancaster, J., 1997. Field experiments on flow refuge in streams. Freshwater Ecology, 37, 569-580. https://doi.org/10.1046/j.13652427.1997.00184.x.

[44] Walker, B., Holling, C.S., Carpenter, S.R., Kinzig, A., 2004. Resilience, adaptability and transformability in socialecological systems. Ecology and Society, 9. http://doi:10.5751/ES-00650-090205.

[45] Brigante, J., Dornfeld, C.B., Novelli, A., Morraye, M.A. Comunidade de macroinvertebrados bentônicos no rio MogiGuaçu. 181-187. In Brigante, J \& Espíndola, E.L.G. (org.), Limnologia Fluvial. Editora RIMA, São Paulo, 2003. 